cerned with optical methods : the microscope for the identification of hair, shreds of clothing or other small particles, for the examination of minute markings on bullets so as to identify the weapon used, or the markings on a cut window bar to identify the bolt cutter used, and, with the addition of polarizing prisms, the identification of soil stains on shoes or clothing. The spectroscope is used for identification of stains of all kinds, ultra-violet light for the identification of materials by their fluorescence, for the detection of erasures in documents or for reading documents written in secret ink invisible in ordinary light. X-rays are used for the examination of suspected parcels without opening them, and infra-red light for reading obliterated writing or printing on paper and other materials.

\section{Manganese Ores}

IN view of the great importance of manganese ores in modern steel manufacture, much interest is attached to a small book by Dr. A. W. Groves on "Manganese" (Second Edition. Imperial Institute, 1938. 3s. 6d. net). It is one of the series of monographs on mineral production. Ores occur in many lands, but large-scale production is confined to the Soviet Union, India, the Gold Coast, the Union of South Africa, Brazil, Egypt and Cuba. It is noteworthy that with the exception of the Soviet Union and to a small extent the United States, all great steelproducing countries have to rely upon imports from distant lands for their supplies of manganese. These ores are thus one of the most essential constituents of ocean trade. The book gives details of occurrence and production in all lands where the ore has been found and ends with a long bibliography.

\section{The Night Sky in January}

ThE moon is full on January 5, and new on January 20. Lunar conjunctions with the planets occur as follows: on January 14 with Mars; on January 16 with Venus; on January 23 with Jupiter and with Saturn on January 26. Mercury, Venus and Mars are morning stars. Mercury is at greatest western elongation $\left(23^{\circ}\right)$ on January 3 , and Venus reaches greatest western elongation $\left(47^{\circ}\right)$ on January 30. Venus rising shortly before $4 \frac{1}{2}$ U.T. is pre-eminently the bright and morning star. Jupiter, southing in the early afternoon, is conspicuous in the evening sky. Saturn is due south shortly after $18^{\mathrm{h}}$ on January 1 . The bright stars of the constellation of Orion and its associated constellations are passing the southern meridian about $22^{\mathrm{h}}$ in midJanuary. The Quadrantids radiating from Draco may be looked for about January 2. On January 1, an occultation of the planet Uranus (mag. 6.0) takes place; at Greenwich the disappearance occurs at $17^{\mathrm{h}} 0 \cdot 1^{\mathrm{m}}$ at position angle $51^{\circ}$ from the north point of the moon's image. On January 26, $\delta$ Piscium $\left(4 \cdot 6^{\mathrm{m}}\right)$ is occulted at $17^{\mathrm{h}} 1 \cdot 2^{\mathrm{m}}$, and on January 30 , $\varepsilon$ Tauri $\left(3 \cdot 6^{\mathrm{m}}\right)$ at $19^{\mathrm{h}} 39 \cdot 2^{\mathrm{m}}$, the respective position angles at disappearance being $12^{\circ}$ and $83^{\circ}$ from the north point.

\section{Announcements}

Prof. Erwin Schrödinger has been appointed by the Fondation Francqui as a visiting professor for the next six months to a "Chaire Francqui" in the University of Ghent, Belgium. His address is : Laboratory of Physics, Plateaustraat 22, Gand, Belgium.

M. EDMOND RoTHÉ, director of the Institute for the Physics of the Earth, University of Strasbourg, has been elected a correspondant for the Section of Astronomy of the Paris Academy of Sciences in succession to the late Prof. P. Stroobant.

Dr. Errol Ivor White has been appointed deputy keeper in the Department of Geology of the British Museum (Natural History) with effect from December 21, and Mr. Frederick Allan Bannister has been appointed deputy keeper in the Department of Mineralogy with effect from December 31. Dr. White entered the Museum as an assistant in 1922. He took the degree of D.Sc. in 1935, and throughout his service at the Museum has specialized on the fossil fishes, upon which he is a recognized authority. Mr. Bannister entered the Museum in 1927 as an assistant keeper and has specialized in the analysis of mineral structure by means of X-rays, in the development of which method he has taken a leading part.

THE annual meeting of the Mathematical Association will be held in King's College, Strand, London, W.C.2, on January 2-3 under the presidency of Mr. W. Hope-Jones. The subject of Mr. Hope-Jones's address will be "Simplicity and Truthfulness in Arithmetic". Discussions on the teaching of applied mathematics in technical colleges, and on the second report on the teaching of geometry have been arranged, and papers by Prof. W. L. Bragg on the symmetry of patterns and by Lord Stamp on education and statistical method in business have been promised. Further information can be obtained from Mr. G. L. Parsons, Peckwater, Eastcote Road, Pinner, Middlesex.

The Government of Cuba has decided to devote a million dollars to the campaign against tuberculosis.

A Ceremony in commemoration of the biologist and physician Lazzaro Spallanzani (1729-1799) will be held at Padua next spring at the same time as the International Congress of Experimental Biology, which will be under the patronage of the Italian Academy.

The Alvarenga do Piauhy (Brazil) Prize for 1939, which is worth about 200 dollars, will be awarded by the College of Physicians of Philadelphia in July next for the best memorial or the best unpublished essay on any branch of medicine. Recent publications brought to the attention of the committee before May I, 1939, will receive attention. Further information can be had from the Committee for the Alvarenga Prize, 19 South Twenty-second Street, Philadelphia, U.S.A. 